\title{
Carbohydrate Metabolism in Agaricus bisporus: Oxidative Pathways in Mycelium and Sporophore
}

\author{
By JOHN B. W. HAMMOND \\ Glasshouse Crops Research Institute, Worthing Road, Littlehampton, \\ Sussex $B N{ }_{1}{ }_{3} P U$
}

(Received 7 April 1977)

\begin{abstract}
The relative rates of the glycolytic pathways were compared in vegetative mycelium and sporophore tissue of Agaricus bisporus. Simple radiorespirometry gave a C-I/C-6 ratio of $8 \cdot 3$ for pileus slices and $4 \cdot 6$ for vegetative mycelium. Glucose-6-phosphate dehydrogenase activity was greater in sporophores than in vegetative mycelium; glucosephosphate isomerase activity was higher in the mycelium. There was no significant difference between mannitol dehydrogenase activities in sporophore and mycelium. The results were consistent with a greater proportion of glucose oxidation occurring via the hexose monophosphate pathway in the sporophore than in the mycelium.
\end{abstract}

\section{INTRODUCTION}

The synthesis of mannitol in Agaricus bisporus (Lange) Imbach is mediated by an NADPHdependent mannitol dehydrogenase using fructose as substrate (Edmundowicz \& Wriston, 1963). Although sporophores accumulate large quantities of mannitol, relatively little is present in the mycelium (Hammond \& Nichols, 1976). Previous work has demonstrated high levels of oxidation by the hexose monophosphate (HM) pathway in $A$. bisporus sporophores (Le Roux, 1967; Graham, 197I). Dütsch \& Rast (1972) found that NADPH produced by the HM pathway was used for mannitol synthesis in $A$. bisporus and proposed a close link between the rates of the two pathways. Strobel \& Kosuge (1965) reported that polyol accumulation in Diplodia viticola was more closely related to glucose-6-phosphate dehydrogenase (G-6-P dehydrogenase) levels than to mannitol dehydrogenase levels. Thus mannitol synthesis appears to be closely related to the HM pathway in more than one fungus. This paper reports experiments testing the suggestion of Hammond \& Nichols (1976) that the difference in mannitol levels between mycelium and sporophore could be due to a lower proportion of oxidation by the HM pathway in the former.

\section{METHODS}

Agaricus bisporus (strains Darlington's 621 and 649) sporophores were grown on commercial compost at the Glasshouse Crops Research Institute Mushroom Unit and harvested at stage 2 ('buttons') (Hammond \& Nichols, 1976). Vegetative mycelium was grown on $2 \%(w / v)$ malt extract agar overlaid with cellophane or in $2 \%(w / v)$ malt extract static liquid culture, and used after 4 to 6 weeks growth.

Radiorespirometry. [U- $\left.{ }^{14} \mathrm{C}\right] \mathrm{Glucose},\left[\mathrm{I}-{ }^{14} \mathrm{C}\right]$ glucose and $\left[6-{ }^{14} \mathrm{C}\right] \mathrm{glucose}$ were obtained from The Radiochemical Centre, Amersham.

Slices of pileus I mm thick (about $50 \mathrm{mg}$ dry weight) from a freshly harvested sporophore were floated in

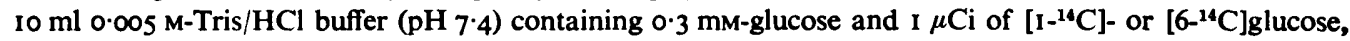
in a $50 \mathrm{ml}$ conical flask. Tissue from the same sporophore was used for comparison of rates of ${ }^{14} \mathrm{CO}_{2}$ production from $\left[{ }^{1-14} \mathrm{C}\right]$ - and $\left[6-{ }^{14} \mathrm{C}\right]$ glucose. Air was drawn through the flasks and $\mathrm{CO}_{2}$ was absorbed by bubbling 
through ethanolamine/methanol $(60: 400, \mathrm{v} / \mathrm{v})$, which was changed at $\mathrm{I}$ or $2 \mathrm{~h}$ intervals. The flasks were shaken continuously.

Cellophane discs bearing mycelium were peeled from the agar substrate and cut in half. Two half discs from separate Petri dishes were placed in a Petri dish containing I $\mathrm{ml} 0.3 \mathrm{mM}$-glucose in buffer and I $\mu \mathrm{Ci}$ $\left[\mathrm{I}^{-{ }^{14} \mathrm{C}} \mathrm{glucose}\right.$, so that the feeding solution formed a film beneath the cellophane. The two remaining halves were placed in another dish containing $\left[6-{ }^{14} \mathrm{C}\right] \mathrm{glucose}$. Each dish was placed in a small polythene bag which was sealed except for the air inlet and outlet tubes. Air was passed over the cultures and the $\mathrm{CO}_{2}$ was collected as above.

All experiments were carried out at $22{ }^{\circ} \mathrm{C}$. The activity of the ${ }^{14} \mathrm{CO}_{2}$ retained by the absorbent was measured by adding an equal quantity of $1 \cdot 2 \%(\mathrm{w} / \mathrm{v}) 2$-(4'-tert-butylphenyl)-5-( $4^{\prime \prime}$-biphenylyl)-1,3,4-oxadiazole (butyl PBD) in toluene and counting with a scintillation counter.

The activity of ${ }^{14} \mathrm{CO}_{2}$ produced from $\left[{ }_{1}{ }^{14} \mathrm{C}\right]-$ and $\left[6-{ }^{14} \mathrm{C}\right] \mathrm{g}$ lucose up to the end of $\mathrm{I}$ Relative Time Unit (RTU) (Wang et al., 1958) was used in calculating the C-1/C-6 ratios. The end of the RTU was taken to be the end of the rapid decrease in ${ }^{14} \mathrm{CO}_{2}$ production from $\left[{ }^{1}-{ }^{14} \mathrm{C}\right] \mathrm{glucose}$; this indicated exhaustion of the labelled substrate added (Wang et al., 1958). Counting procedures for the feeding solution were as described by Hammond \& Nichols (1977).

Enzyme assays. Extracts were prepared by grinding $1.5 \mathrm{~g}$ fresh weight of tissue in liquid nitrogen and homogenizing in $0.1 \mathrm{M}-\mathrm{Tris} / \mathrm{HCl}$ buffer $\left(\mathrm{pH}^{7} .5\right)$. For $\mathrm{G}-6-\mathrm{P}$ dehydrogenase assays, the buffer contained $50 \mathrm{~mm}$-mercaptoethanol and I mM-EDTA. The homogenate was centrifuged for $10 \mathrm{~min}$ at $6000 \mathrm{~g}$. The extracts were dialysed overnight against distilled water, except for those to be assayed for G-6-P dehydrogenase which were used fresh. All operations were carried out at $4{ }^{\circ} \mathrm{C}$.

Glucosephosphate isomerase (D-glucose-6-phosphate ketol-isomerase; EC 5.3.I.9) was assayed as described by Hammond \& Nichols (1977).

Glucose-6-phosphate dehydrogenase (D-glucose-6-phosphate:NADP+ I-oxidoreductase; EC I I I I . 49) was assayed by the method of De Moss (1955). The assay mixture contained $5.3 \mathrm{~mm}$-glucose 6-phosphate, $0.2 \mathrm{~mm}-\mathrm{NADP}^{+}$and $3.3 \mathrm{mM}-\mathrm{MgCl}_{2}$ in $0.1 \mathrm{M}-\mathrm{Tris} / \mathrm{HCl}$ buffer $(\mathrm{pH} 7 \cdot 7)$. The rate of change of absorbance at $340 \mathrm{~nm}$ was measured at $30^{\circ} \mathrm{C}$. No NADP+ reduction occurred in the absence of glucose 6-phosphate. 6-Phosphogluconate dehydrogenase activity was corrected for, after repeating the assay in the presence of added dialysed 6-phosphogluconate dehydrogenase (Sigma) (Edmundson \& Ashworth, 1972).

Mannitol dehydrogenase (D-mannitol:NADP ${ }^{+}$2-oxidoreductase; EC I I I I I I 138) assay was by the method of Edmundowicz \& Wriston (1963). The mixture contained $0.09 \mathrm{~mm}-\mathrm{NADPH}$ and $3.45 \mathrm{~mm}$-fructose in $0.1 \mathrm{M}-\mathrm{Tris} / \mathrm{HCl}$ buffer $(\mathrm{pH} \mathrm{8.0})$. The change in absorbance at $340 \mathrm{~nm}$ was followed at $30^{\circ} \mathrm{C}$.

Protein concentrations were measured by the method of Lowry et al. (1951) using bovine serum albumin standards. Units of activity were as follows: glucosephosphate isomerase, nmol fructose 6-phosphate produced $\min ^{-1}$; G-6-P dehydrogenase, nmol NADP+ ${ }^{+}$reduced $\min ^{-1}$; mannitol dehydrogenase, nmol NADPH oxidized $\mathrm{min}^{-1}$. A molar extinction coefficient of $6.2 \times 10^{3} \mathrm{M}^{-1} \mathrm{~cm}^{-1}$ was assumed for NADPH.

\section{RESULTS AND DISCUSSION}

A large peak in ${ }^{14} \mathrm{CO}_{2}$ production from $\left[\mathrm{II}^{14} \mathrm{C}\right.$ ]glucose in the first few hours, with low production from $\left[6^{-14} \mathrm{C}\right]$ glucose, occurred in both sporophore and mycelium (Fig. I). This is consistent with the operation of the HM pathway in both types of hypha. For the calculations I RTU was taken as $8 \mathrm{~h}$. Table I presents calculated C-I/C-6 ratios from several experiments. Values for mycelium were about $50 \%$ lower than those for pileus tissue. This indicates a lower participation, perhaps by $50 \%$, of the HM pathway in glucose oxidation in the mycelium compared with the pileus.

Although the object of the experiments was to compare mycelium and sporophore rather than to determine absolute levels of HM pathway participation, it is interesting that the values reported here indicate lower HM pathway activity than those obtained by Le Roux (1967) for gill tissue. Le Roux gave a value of $56 \%$ and his results indicated that pileus tissue had a more active HM pathway. This difference may be due to the use of different methods or to variation in the materials. More precise methods than those described here are necessary for absolute determinations of oxidative pathways.

The results from the enzyme assays (Table 2) showed a similar pattern to those from radiorespirometry. Enzyme activities were similar in extracts from agar and liquid cultured mycelium; there appeared to be a slight increase in G-6-P dehydrogenase activity with myce- 


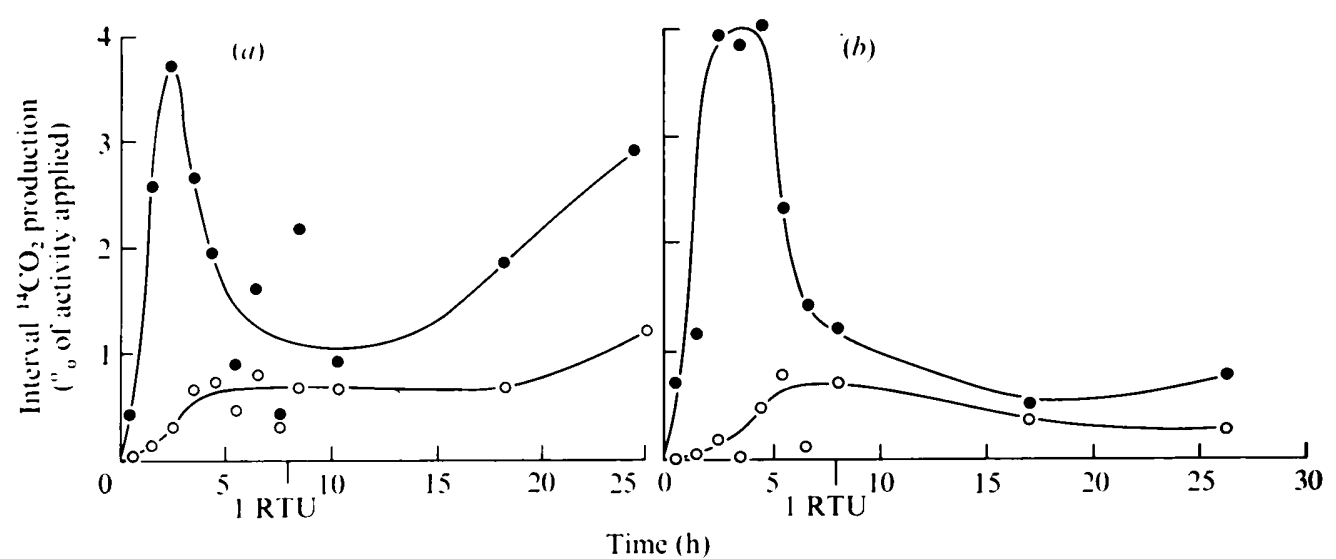

Fig. I. Time course of ${ }^{14} \mathrm{CO}_{2}$ production during radiorespirometry from $\left[\mathrm{I}^{-14} \mathrm{C}\right]-$ or $\left[6-{ }^{14} \mathrm{C}\right] \mathrm{glucose}$ by $(a)$ vegetative mycelium, $(b)$ pileus slices. $O,\left[I^{14} \mathrm{C}\right]$ glucose; $O,\left[6-{ }^{14} \mathrm{C}\right]$ glucose. Lines fitted by eye.

Table I. C-I/C-6 ratios for mycelium and pileus slices calculated from radiorespirometry experiments

$\begin{array}{lcc} & \begin{array}{c}\text { Vegetative } \\ \text { mycelium }\end{array} & \text { Pileus slices } \\ \text { Experiment I } & 6 \cdot 5 & 6.7 \\ \text { Experiment 2 } & 5 \cdot 2 & - \\ & 4 \cdot 0 & 6 \cdot 1 \\ \text { Experiment 3 } & 3 \cdot 2 & 11 \cdot 5 \\ & 4 \cdot 2 & 7 \cdot 0 \\ \text { Mean } \pm \text { S.E.M. } & 4 \cdot 2 & 10.3 \\ & 4.6 \pm 0.5 & 8 \cdot 3 \pm I \cdot I\end{array}$

Table 2. Specific activities of glucose-6-phosphate dehydrogenase, glucosephosphate isomerase and mannitol dehydrogenase in vegetative mycelium and sporophores

Results, expressed as units (mg protein) ${ }^{-1}$, show mean values (number of determinations in parentheses) \pm S.E.M.

$\begin{array}{lcc} & \text { Vegetative mycelium } & \text { Sporophores } \\ \begin{array}{l}\text { Glucose-6-phosphate } \\ \text { dehydrogenase }\end{array} & 33 \pm 4 \text { (12) } & 73 \pm 10 \text { (12) } \\ \begin{array}{l}\text { Glucosephosphate } \\ \text { isomerase }\end{array} & 197 \pm 5 \text { (9) } & 77 \pm 3(7) \\ \text { Mannitol dehydrogenase } & 4.9 \pm 0.8(8) & 6.8 \pm 1 \cdot 4(6)\end{array}$

lial age. G-6-P dehydrogenase activity in the sporophore was twice that in the mycelium, suggesting a more active HM pathway in the former; glucosephosphate isomerase was more active in the mycelium, which is consistent with greater glucose oxidation via the EmbdenMeyerhof-Parnas pathway. Addition of 6-phosphogluconate dehydrogenase led to a 5 to $6 \%$ increase in reaction rate in G-6-P dehydrogenase assays of mycelium and sporophore extracts. This implies that endogenous 6-phosphogluconate dehydrogenase activity was slightly lower than that of G-6-P dehydrogenase.

Mannitol dehydrogenase activity was similar in sporophore and mycelium. Thus a simple deficiency of this enzyme cannot be responsible for the low levels of mannitol in the mycelium.

The results from radiorespirometry and the enzyme assays were consistent with higher activity of the HM pathway in the sporophore than in the mycelium of $A$. bisporus. Calculations using rates of respiration and mannitol accumulation (Hammond, unpublished 
data) suggest that the increased HM pathway activity in the sporophore may be just great enough to account for the increase in mannitol accumulation over that in the mycelium.

The experiments described compare compost-grown sporophores with vegetative mycelium grown on malt extract media, since it is not possible to induce $A$. bisporus to fruit on artificial media. It is conceivable that different HM pathway levels prevail in sporophore-producing mycelium; however, previous work has shown that soluble carbohydrate levels are very similar in axenic and fruiting cultures (Hammond \& Nichols, 1976). The growth rate of mycelium in compost and on malt extract is also similar (D. Wood, personal communication). Thus it is possible that there is no great difference in the metabolic pathways under study between mycelium grown on agar and that which is grown on compost and can produce sporophores. If this is so, the difference in mannitol content between sporophores at stage 2 and their supporting mycelium, as well as between sporophores and vegetative mycelium, may be explained by a higher level of HM pathway operation in the sporophore.

Schwalb (1974) and Moore \& Ewaze (1976) found that G-6-P dehydrogenase levels were greater in immature fruit bodies than vegetative mycelium of Schizophyllum commune and Coprinus cinereus respectively; this also appears to be true in $A$. bisporus. Hexose monophosphate pathway activation may be a general feature in the initiation and early growth of basidiomycete fruit bodies.

\section{REFERENCES}

DE Moss, R. D. (1955). Glucose-6-phosphate dehydrogenase. Methods in Enzymology I, 330-331.

Dütsch, G. A. \& RAST, D. (1972). Biochemische Beziehung zwischen Mannitbildung und Hexosemonophosphatzyklus in Agaricus bisporus. Phytochemistry 11, 2677-268I.

Edmundowicz, J. M. \& WRISTon, J. C., JR (1963). Mannitol dehydrogenase from Agaricus campestris. Journal of Biological Chemistry 238, 3539-354I.

Edmundon, T. D. \& Ashworth, J. M. (1972). 6-Phosphogluconate dehydrogenase and the assay of uridine diphosphate glucose phosphorylase in the cellular slime mould Dictyostelium discoideum. Biochemical Journal 126, 593-600.

Graham, D. G. (1971). Protein and energy metabolism of mitochondria of the common meadow mushroom Agaricus bisporus in extracellular culture. Ph.D. thesis, Duke University, U.S.A.

Hammond, J. B. W. \& Nichols, R. (1976). Carbohydrate metabolism in Agaricus bisporus (Lange) Sing.: changes in soluble carbohydrates during growth of mycelium and sporophore. Journal of General Microbiology 93, 309-320.

Hammond, J. B. W. \& Nichols, R. (1977). Carbohydrate metabolism in Agaricus bisporus (Lange) Imbach: metabolism of ${ }^{14} \mathrm{C}$-labelled sugars by sporophores and mycelium. New Phytologist (in the Press).
LE Roux, P. (1967). Importance relative de la voie des pentoses phosphates et de la glycolyse dans le carpophore d'Agaricus bisporus. Annales de physiologie végétale $9,349-363$.

Lowry, O. H., Rosebrough, N. J., FARr, A. L. \& RaNDALL, R. J. (I95I). Protein measurement with the Folin phenol reagent. Journal of Biological Chemistry 193, 265-275.

MoOre, D. \& EwAZE, J. O. (1976). Activities of some enzymes involved in metabolism of carbohydrate during sporophore development in Coprinus cinereus. Journal of General Microbiology 97, 313-322.

SchwalB, M. N. (1974). Changes in activity of enzymes metabolising glucose-6-phosphate during development of the basidiomycete Schizophyllum commune. Developmental Biology 40, 84-89.

Strobel, G. A. \& Kosuge, T. (1965). Polyol metabolism in Diplodia viticola Desm. Archives of Biochemistry and Biophysics 109, 622-626.

Wang, C. H., Stern, I., Gilmour, C. M., KlungSOYR, S., Reed, D. J., Bialy, J. J., Christensen, B. E. \& Cheldelin, V. H. (1958). Comparative study of glucose catabolism by the radiorespirometric method. Journal of Bacteriology 76, 207216. 